\title{
Correction to: Reducing external costs of nitrogen pollution by relocation of pig production between regions in the European Union
}

\author{
Hans J. M. van Grinsven ${ }^{1}$ • Jan D. van Dam ${ }^{1}$ • Jan Peter Lesschen ${ }^{2}$ • Marloes H. G. Timmers ${ }^{1,2,3}$ • Gerard L. Velthof ${ }^{2}$. \\ Luis Lassaletta $^{1,4}$
}

Published online: 31 May 2019

(C) The Author(s) 2019

\section{Correction to: Regional Environmental Change https://doi.org/10.1007/s10113-018-1335-5}

The article Reducing external costs of nitrogen pollution by relocation of pig production between regions in the European Union, written by Hans J. M. van Grinsven, Jan D. van Dam, Jan Peter Lesschen, Marloes H. G. Timmers, Gerard L. Velthof, Luis Lassaletta, was originally published electronically on the publisher's internet portal (currently SpringerLink) on 28 May 2018 without open access. With the author(s)' decision to opt for Open Choice the copyright of the article changed on April 2019 to (C) The Author(s) 2019 and the article is forthwith distributed under the terms of the Creative Commons Attribution 4.0 International License (http:// creativecommons.org/licenses/by/4.0/), which permits use, duplication, adaptation, distribution and reproduction in any medium or format, as long as you give appropriate credit to the original author(s) and the source, provide a link to the Creative Commons license and indicate if changes were made.

The original article was corrected.

Open Access This article is distributed under the terms of the Creative Commons Attribution 4.0 International License (http:// creativecommons.org/licenses/by/4.0/), which permits unrestricted use, distribution, and reproduction in any medium, provided you give appropriate credit to the original author(s) and the source, provide a link to the Creative Commons license, and indicate if changes were made.

Publisher's note Springer Nature remains neutral with regard to jurisdictional claims in published maps and institutional affiliations.
The online version of the original article can be found at https://doi.org/ 10.1007/s10113-018-1335-5

Hans J. M. van Grinsven

hans.vangrinsven@pbl.nl

Jan D. van Dam

jan.vandam@pbl.nl

Jan Peter Lesschen

janpeter.lesschen@wur.nl

Marloes H. G. Timmers

marloes.timmers@bro.nl

Gerard L. Velthof

gerard.velthof@wur.nl
Luis Lassaletta

Luis.Lassaletta@upm.es

1 PBL Netherlands Environmental Assessment Agency, PO Box 30314, 2500, GH The Hague, The Netherlands

2 Wageningen Environmental Research, Wageningen University and Research, PO Box 47, 6700 AA Wageningen, The Netherlands

3 Wageningen University and intern at PBL, The Hague, The Netherlands

4 Present address: Research Center for the Management of Environmental and Agricultural Risks (CEIGRAM), Universidad Politécnica de Madrid, 28040 Madrid, Spain 